\title{
Corrosion Health Monitoring System for Steel Ship Structures
}

\author{
P. K. Satheesh Babu, A. Mathiazhagan, and C. G. Nandakumar
}

\begin{abstract}
Corrosion represents one of the largest through life cost component of ships. Ship owners and operators recognize that combating corrosion significantly impacts the vessels' reliability, availability and through life costs. Primary objective of this paper is to review various inspections, monitoring systems and life cycle management with respect to corrosion control of ships and to develop the concept of "Corrosion Health" $(\mathrm{CH})$ which would quantify the extent of corrosion at any point of ships' operational life. A system approach in which the ship structure is considered as a corrosion system and divided into several corrosion zones, with distinct characteristics, is presented. Various corrosion assessment criteria for assessment of corrosion condition are listed. A CH rating system for representation of complex corrosion condition with a numeric number along with recommendations for repair/maintenance action is also discussed.
\end{abstract}

Index Terms-Corrosion control of ships, corrosion health, corrosion of ship structure, marine corrosion, monitoring systems, ship inspections.

\section{INTRODUCTION}

In a modern business environment, successful ship owners connot tolerate major corrosion failures involving injuries, fatalities, unscheduled maintenance and environmental contamination. Ship owners and operators recognize that combating corrosion impacts significantly upon vessels' reliability, availability, through life costs and budget availability for future projects. Considerable efforts are therefore expended on corrosion control at the various stages of ship's life cycle.

Decisions regarding the future integrity of ship structure or its components depend on an accurate assessment of corrosion and rate of deterioration. With knowledge on corrosion health of the structure, informed decisions can be made as to the type, cost and urgency of repair works. Corrosion inspections and monitoring are used to determine the corrosion condition of ship structure and to determine the effectiveness of corrosion control systems. Primary objective of this paper is to review various inspections, monitoring systems and life cycle management with respect to corrosion control of ships and to develop the concept of "Corrosion Health" which would quantify the extent of corrosion at any point of steel ships' operational life. The advantages of this

Manuscript received January 15, 2014; revised March 7, 2014. This work was carried out as part of research work Dept of Ship Technology, Cochin University of Science and Technology.

The authors are with the Dept. of Ship Technology, Cochin University of Science and Technology, India (e-mail: pksatheeshbabu@yahoo.com, alagan@cusat@ac.in, nandu@cusat.ac.in). concept in improving the platform availability and recommended values of $\mathrm{CH}$ are also presented. Irrespective of the age of the ship or trading areas, ship owners/operators have now begun to see the benefits of preserving the outer hull and internals in terms of repair costs and downtime.

\section{CORROSION OF SHIP STRUCTURES}

\section{A. Corrosion in Marine Environment}

It is generally accepted that the marine environment, that combines the effects of saline seawater, salt laden air, rain, dew, condensation, localized high temperature and the corrosive effects of combustion gases is the most corrosive of naturally occurring environments [1]. The mechanics of corrosion in marine structures is well understood and in addition to general corrosion (which reduces the plate thickness uniformly); there are other types of more localized corrosion patterns identifiable in ships [2].

The hull being constantly exposed to the corrosive seawater environment experiences general corrosion but it is also likely to experience pitting, galvanic corrosion and others. Pitting occurs when the hull is exposed to stagnant or slow moving water like that found in dockyard basins. The hull of a vessel may also experience stray current corrosion which occurs when welding equipment is incorrectly earthed. Galvanic corrosion may exist between the hull and a more noble material. Other forms of corrosion observed in ship structures are crevice corrosion, microbiological corrosion, stress corrosion cracking, erosion corrosion, high temperature corrosion, corrosion under lagging and heat exchanger corrosion.

\section{B. Impact of Corrosion}

Mitigating unexpected corrosion can be very expensive in terms of direct cost and it also impacts heavily on platform availability. Corrosion can interfere with the operation of ship and impose increased loading stresses, accelerate deterioration of structure, and increases the hydrodynamic drag. Corrosion can cause the ship to fail prematurely resulting in loss of investment, safety and structural integrity. If a ship and its systems were designed with built-in corrosion resistance, this would result in less planned and unplanned maintenance and in substantial saving in through life costs.

\section{Corrosion Control Measures}

Application of efficient corrosion control measures during various stages of lifecycle is crucial to mitigation of corrosion failures. The recognized methods for corrosion 
protection of ships are illustrated in several publications [3], [4]. Corrosion prevention and control methods include selection of right materials, right method of fabrication, protective coatings and use of cathodic protection (sacrificial anodes or Impressed Current Cathodic Protection) systems. Other measures such as use of vapour phase inhibitors and dehumidification are also used in certain cases. Classification Societies have promulgated standards for selection, application, inspection and maintenance of corrosion protections systems for different components of ship structures. A comprehensive review of existing hull coating system and recommendations are presented in [5].

\section{CORROSION INSPECTIONS AND MONITORING}

Corrosion inspections may be used to acquire data on existing condition of ship structure. Such data may need to be converted into useful information for incorporating in a corrosion management programme. There have been advances in the field of corrosion monitoring tools, process control tools and application of knowledge based systems. Ship structure inspections typically cover the assessment of coating, corrosion, cathodic protection, possible structural defects, cleanliness of compartments and, most importantly, the remaining thickness of plates and profiles [6].

Corrosion monitoring is very complex because there are a number of critical areas susceptible to different types of corrosion, nature of corrosion may be uniform or localized, rate of corrosion varies substantially at different locations and there is no single measurement technique that will detect all corrosion conditions [7].

\section{A. Inspection Regime}

TABLE I: SHIP INSPECTIONS

\begin{tabular}{|c|c|c|c|}
\hline Organization & Survey Types & $\begin{array}{l}\text { Inspection Area/ } \\
\text { Item }\end{array}$ & Applicability \\
\hline IMO & \multirow{2}{*}{$\begin{array}{c}\text { Initial, } \\
\text { Annual, } \\
\text { Intermediate, } \\
\text { Periodical/ } \\
\text { Renewal }\end{array}$} & $\begin{array}{c}\text { Safety, Pollution, } \\
\text { Loadline, ISM, } \\
\text { ISPS }\end{array}$ & \multirow{4}{*}{$\begin{array}{l}\text { All types of } \\
\text { ships }\end{array}$} \\
\hline $\begin{array}{c}\text { Classification } \\
\text { Societies }\end{array}$ & & Hull \& Machinery & \\
\hline Port State & On Purpose & \multirow{2}{*}{$\begin{array}{c}\text { Hull and } \\
\text { Machinery } \\
\text { Safety, Pollution, } \\
\text { Load } \\
\text { line }\end{array}$} & \\
\hline Flag State & $\begin{array}{c}\text { Initial } \\
\text { Occasional, } \\
\text { Periodical }\end{array}$ & & \\
\hline $\begin{array}{l}\text { Insurance } \\
\text { Company }\end{array}$ & $\begin{array}{l}\text { Insurance } \\
\text { Inspections }\end{array}$ & $\begin{array}{l}\text { CAS / ESP } \\
\text { (mandatory) }\end{array}$ & $\begin{array}{c}\text { Tanker, Bulk } \\
\text { Carriers } \\
\text { (mainly) }\end{array}$ \\
\hline $\begin{array}{l}\text { Terminal } \\
\text { Operators }\end{array}$ & $\begin{array}{l}\text { Safety \& } \\
\text { pollution } \\
\text { prevention } \\
\text { survey }\end{array}$ & $\begin{array}{c}\text { Cargo handling } \\
\text { equipment, } \\
\text { Procedures }\end{array}$ & \multirow{3}{*}{$\begin{array}{c}\text { Oil \& } \\
\text { Chemical } \\
\text { Tanker, Bulk } \\
\text { Carriers, Gas } \\
\text { Carriers }\end{array}$} \\
\hline $\begin{array}{c}\text { Cargo } \\
\text { Owners }\end{array}$ & \multirow{2}{*}{$\begin{array}{c}\text { Charterer/ } \\
\text { Vetting } \\
\text { (oil majors, } \\
\text { CDI, } \\
\text { OCIMF/SIRE } \\
\text {, etc.) }\end{array}$} & \multirow{2}{*}{$\begin{array}{c}\text { CAP, Cargo } \\
\text { operation } \\
\text { Survey } \\
\text { on purpose, } \\
\text { Risk-based } \\
\text { analyses }\end{array}$} & \\
\hline Ship Owners & & & \\
\hline
\end{tabular}

\section{B. Hull Inspection and Maintenance Schemes}

Owner's Hull Inspections and Maintenance Programmes
(HIMP) are encouraged as a means of maintaining compliance with classification and statutory requirements, but are not considered alternatives to mandatory requirements. Major Classification Societies have published guidance for implementation of HIMP and provide software tools (with internet access capability) to assist owners in planning inspections and storing data of vessel conditions [9]. See Table II.

TABLE II: GUIDANCE AND SOFTWARE PROVIDED BY CLASSIFICATION SOCIETIES TO ASSIST INSPECTION

\begin{tabular}{|c|c|c|c|c|}
\hline Class & $\begin{array}{l}\text { Guidance } \\
\text { for } \\
\text { Qualified } \\
\text { Inspectors }\end{array}$ & $\begin{array}{c}\text { Hull } \\
\text { Monitoring } \\
\text { Guidance }\end{array}$ & $\begin{array}{l}\text { Online } \\
\text { access } \\
\text { of } \\
\text { inspecti } \\
\text { on } \\
\text { record }\end{array}$ & $\begin{array}{c}\text { Software for } \\
\text { inspection and } \\
\text { data } \\
\text { management }\end{array}$ \\
\hline ABS & Yes & Yes & Yes & Safenet \\
\hline DNV & Yes & Yes & Yes & Nauticus \\
\hline $\mathrm{BV}$ & Yes & Yes & Yes & $\begin{array}{l}\text { VeriSTAR Hull } \\
5\end{array}$ \\
\hline GL & $\begin{array}{c}\text { PSC } \\
\text { Checklist }\end{array}$ & Yes & Yes & $\begin{array}{c}\text { Poseidon, } \\
\text { Pegasus, } \\
\text { ShipManager }\end{array}$ \\
\hline LR & $\begin{array}{c}\text { PSC } \\
\text { Checklist }\end{array}$ & Yes & Yes & $\begin{array}{c}\text { ClassDirect } \\
\text { Live, } \\
\text { ShipRight, Hull } \\
\text { Integrity }\end{array}$ \\
\hline $\mathrm{KR}$ & Yes & Yes & Yes & $\begin{array}{c}\text { InfoShips, } \\
\text { SeaTrust }\end{array}$ \\
\hline NKK & - & Yes & Yes & $\begin{array}{l}\text { PrimeShip- } \\
\text { HULLCare }\end{array}$ \\
\hline RINA & $\begin{array}{c}\text { PSC } \\
\text { Checklist }\end{array}$ & Yes & Yes & Leonardo Hull \\
\hline
\end{tabular}

Current inspection regime, including mandatory surveys required by IMO, Classification Societies, Flag States, Port States, and voluntary/ recommended inspections are summarized in Table I. While there seems to be a considerable amount of overlapping between mandatory and industry-driven inspections, Classification Societies play a major role in the inspection regime, performing statutory surveys in addition to class required surveys, and offering consulting services (e.g., CAP) for some types of ships [8].

\section{Guidelines for Corrosion Inspections}

Strategies for the inspection, maintenance and repair of the parts that can corrode and their protections systems, should be planned and implemented. Permanent means of access, such as ladders, should also be carefully maintained as they are crucial to the corrosion protection regime. Successful corrosion monitoring systems have the potential to achieve goals such as improved safety, reduced downtime and maintenance costs, early warning system before major damage, reduction in pollution and contamination, reduction in operating costs and extension of operational life. Following guidelines may be considered in determining the specific threats for ship structures during corrosion inspections:

1) Corrosion usually starts in areas of coating damage, and areas where the coating can be of poor quality e.g. weld seams, edges, and notches, etc.

2) Stress and strain caused by overloading, reductions in steel thickness as a result of corrosion, repair works, 
wear, dents, etc., may produce damage to coatings.

3) Vibration and stresses may result in increased corrosion and cracks.

4) Welds or Heat-Affected Zones, where coating may be of poor quality due to poor pretreatment or where welding work has been done after the coating has been applied and not properly repaired.

5) Complex shaped structures with poor access, which make it difficult for inspection or to provide efficient protection, are particularly liable to suffer from undetected corrosion.

6) Horizontal surfaces or areas with inadequate drainage or where foreign matter deposits are present, may suffer significant corrosion.

7) Steel surfaces hidden under isolating materials used for fire protection are prone to corrosion.

8) Uniform corrosion over a long period of time can have serious consequences for the structural integrity.

\section{Corrosion Monitoring Techniques}

Corrosion assessment techniques may be broadly classified into "Direct Measurement Techniques" and "Indirect Measurement Techniques". Direct techniques measures parameters directly affected by corrosion processes while indirect techniques provide data on parameters that either affect or are affected by the corrosivity of the environment or by the products of corrosion process. List of techniques are summarized in [7].

\section{Corrosion Health Assessment}

In order to minimize unscheduled maintenance periods, which are the highest cost drivers and readiness degrader, the need for monitoring structural components for Corrosion Health $(\mathrm{CH})$ is important. Investments in technologies such as Condition Based Maintenance (CBM), Structural Health Monitoring (SHM), Prognostics and Health Management (PHM), and others are critical to both effectiveness and affordability [10]. Some of the potential benefits of such a system are better understanding of the materials, inputs for future structural designs, enhancing confidential levels, aiding decision making process of life extension programs or future sales of ships and providing monitoring capability for damage in hard to reach areas or hidden structures, thereby minimizing the need for expensive tear-down inspections.

\section{A. Corrosion Management}

Successful management of corrosion means that susceptibility of corrosion is identified and the associated risks are minimized by implementation of suitable action before major damage is occurred to the structures. Use of corrosion inspection and monitoring in a proactive way (determining the deterioration rate and actions to change the rate) and predictive maintenance are effective strategies for corrosion management. Corrosion management is the overall management system which is concerned with the development, implementation, reviews, and maintenance of the corrosion policy [11]. Corrosion monitoring programs are to make a useful contribution toward the management of corrosion control, that is, to have a real impact on safety and profitability. Data collected with corrosion monitoring systems will be used for more informed decision making than to gather dust in a filing cabinet.

\section{B. Ship Corrosion Zones}

A system approach in which the whole ship structure may be considered as a "Corrosion System" is proposed for development of $\mathrm{CH}$ monitoring system [12]. Corrosion susceptible areas of the ship structure may be grouped into "Corrosion Zones" based on exposure conditions, characteristics of envisaged corrosion and corrosion protection systems. A typical corrosion zone approach for offshore structures is presented in [13]. Each of the corrosion zones encounter different types corrosion problems and also the severity of consequences. The corrosion zones identified for ship structures and their characteristics are described below:

1) Submerged Zone. Continuously submerged in seawater and include underwater hull and appendages (rudder, propeller, bilge keel, shaft brackets etc). This zone is protected against corrosion using a combination of compatible coatings and Cathodic Protection (CP). The paint comprises of both anti corrosive and anti fouling coatings. CP can be either by a sacrificial anode system or impressed current cathodic protection system. The CP system should be able to function once coating damage or deterioration has occurred.

2) The Splash Zone. This zone is subjected to one of the most aggressive marine environments, because of exposure to fully aerated seawater, repeated wetting and drying, UV radiation, and possibly salt build up. Corrosion in this zone can occur at a rapid rate, causing severe localized or general thickness loss, if left unattended. The $\mathrm{CP}$ cannot be used to protect it, since the upper splash zone (above the draft) is not fully and continuously immersed. Consequently suitable coatings and adding sacrificial steel thickness (corrosion addition) are the only possible methods of corrosion control.

3) Atmospheric Zone. The components of this zone include side shell above Splash Zone, Main Deck/ Helo Deck and Super Structure. Coatings are the only cost-effective means to control atmospheric corrosion in this zone and they must be flexible and resistant to UV radiation.

4) Ballast Tanks Zone. Ballast tanks generally pose the highest threat, because they contain seawater, which is at varying levels inside the tank. They are heavily exposed to sloshing sea water, cyclic changes of temperature and hydrostatic pressure, repeated wetting and drying, often of complex construction, with difficult access, insufficient drainage, etc. High flow rates near inlets and outlets can result in local erosion and increased corrosion. Presence of sand particles in the ballast water is also a major concern. These tanks require a combination of coating and CP to control corrosion in locations where the tanks are submerged. Sacrificial anode CP is exclusively used in this case, because of the changing water levels and possibility of hydrogen evolution. The cathodic protection maybe ineffective in 
water containing hydrocarbons.

5) Cargo Tanks/ Holds Zone. It is high wear and tear area and also prone to corrosion with some cargoes. Application of suitable coating system is the only practical corrosion control method. The coatings should be corrosion-inhibiting, free from pores, and easy to clean. The coating should also resist the cargo to be transported and substances released by cargo, tank cleaning procedures, and cross-contamination between different cargoes and ballast water. They must not contaminate or affect the colour or taste of the cargo, particularly cargoes intended for human consumption and pure chemical cargoes (which require coatings systems approved by the appropriate regulatory agency). Recoating is not easily possible without lay-up of ships [14].

6) Other Internal Structures Zone. This zone includes other tanks (fuel, fresh water, grey water, black water) bilges, void spaces, accommodation areas, etc. Suitable coating as per the classification society guidelines is to be applied for corrosion control.

\section{Stages in Corrosion Health (CH) Assessment}

A six stage approach is envisaged for the development of $\mathrm{CH}$ Concept for the ship structure. Development of overall corrosion control strategy is the starting point of the system. The strategy must consists of mechanisms for determining the contributing factors, monitoring corrosion activity in real time, adopting system integration approach for correlating data in real time, record keeping, and continuous review of corrosion status. The various stages in the $\mathrm{CH}$ assessment system and their descriptions are summarized in Table III.

Depending on the complexity of corrosion zones, they may be subdivided to number of subzones or compartments. For example, the submerged and splash zones may be divided into midship region (port \& starboard), fore end (port \& starboard), aft end (port \& starboard), etc for systematic recording of corrosion data. The atmospheric zones may be subdivided into ship side (port \& starboard), main deck, helo deck, superstructure etc. Each ballast tank may be considered as separate subzones of ballast tank zone. Similarly cargo spaces and other spaces may be included in the last two zones. The corrosion of subzone components are assessed based on the stipulated inspection criteria. The most critical case is to be considered for determining the $\mathrm{CH}$ for corrosion zones. Finally the $\mathrm{CH}$ for the whole structure is determined from the $\mathrm{CH}$ values of corrosion zones.

\section{Recommended Corrosion Health (CH) Ratings}

Representation of complex corrosion condition of ship structure with a numeric number along with explanations will be highly advantageous. A rating system from 10 to 5 , with decrease in $\mathrm{CH}$ is recommended. The suggested $\mathrm{CH}$ ratings with descriptions and recommendations are summarized in Table IV. The effort of the ship owner should be to maintain a minimum $\mathrm{CH}$ of 7 and above throughout ship's operational life. Higher the $\mathrm{CH}$ values better will be corrosion health condition of ship structure. Ships with $\mathrm{CH}$ of 5 must undergo immediate remedial actions/ extensive repairs to improve $\mathrm{CH}$ rating to 7 and above prior to further operations.
TABLE III: STAGES IN CORROSION HEALTH ASSESSMENT

\begin{tabular}{|c|c|}
\hline Stage & Description \\
\hline 1 & $\begin{array}{c}\text { Define Corrosion Zones } \\
\text { Divide the ship structure to a number of Corrosion Zones }\end{array}$ \\
\hline 2 & $\begin{array}{l}\text { Pre- Assessment } \\
\text { Collection of following data for each Corrosion Zone, which } \\
\text { can be used for pre-assessment of zones } \\
\text { - Design data } \\
\text { - Construction data } \\
\text { - Environment data } \\
\text { Corrosion Control data } \\
\text { - Maintenance data }\end{array}$ \\
\hline 3 & $\begin{array}{l}\text { Selection of Assessment Techniques } \\
\text { Decisions on use suitable assessment techniques for each } \\
\text { Corrosion Zone } \\
\text { - } \quad \text { Visual survey } \\
\text { - Hammer survey } \\
\text { - } \quad \text { Photographic } \\
\text { - Non Destructive Tests }\end{array}$ \\
\hline 4 & $\begin{array}{l}\text { Corrosion Assessment Criteria } \\
\text { Carry out inspections and rate the structure condition based on } \\
\text { following inspection criteria: } \\
\text { - Coating Failure } \\
\text { - Ineffective cathodic Protection } \\
\text { - Uniform/ General corrosion } \\
\text { Fouling/ Microbiological corrosion } \\
\text { Defects/ Distortion leading to corrosion } \\
\text { drainage, evidence of galvanic coupling, stress corrosion } \\
\text { cracking etc). }\end{array}$ \\
\hline 5 & $\begin{array}{l}\text { Corrosion Health of Individual Zones } \\
\text { Determine the } \mathrm{CH} \text { condition of zones based on a suitable rating } \\
\text { scale, which would quantify the extent of corrosion in that } \\
\text { particular zone }\end{array}$ \\
\hline 6 & $\begin{array}{c}\text { Corrosion Health of Ship Structure } \\
\text { Determine the } \mathrm{CH} \text { of overall ship structure based on the } \\
\text { individual corrosion health values of zones, which would } \\
\text { quantify extent of corrosion of ship structure. }\end{array}$ \\
\hline
\end{tabular}

TABLE IV: CORROSION HEALTH RATING AND DESCRIPTIONS

\begin{tabular}{|c|c|c|}
\hline $\begin{array}{c}\text { Corrosion } \\
\text { Health, CH } \\
\text { (Zone/ } \\
\text { Overall) }\end{array}$ & $\begin{array}{c}\text { Rating } \\
\text { Description }\end{array}$ & Recommendations \\
\hline 10 & $\begin{array}{l}\text { As built } \\
\text { condition }\end{array}$ & NIL \\
\hline 9 & Excellent & $\begin{array}{l}\text { No repair/ maintenance required. Less } \\
\text { than } 20 \% \text { of corrosion margin wasted }\end{array}$ \\
\hline 8 & Very Good & $\begin{array}{l}\text { No repair/ maintenance required, close } \\
\text { monitoring of critical areas required. Less } \\
\text { than } 30 \% \text { of corrosion margin wasted }\end{array}$ \\
\hline 7 & Good & $\begin{array}{l}\text { Deficiencies are minor and to be attended } \\
\text { in the next planned maintenance. } \\
\text { Between } 30-60 \% \text { of corrosion margin } \\
\text { wasted }\end{array}$ \\
\hline 6 & Satisfactory & $\begin{array}{c}\text { Substantial local corrosion and } \\
\text { immediate possible repairs to be } \\
\text { undertaken. } \\
\text { Between } 60-100 \% \text { corrosion margin } \\
\text { wasted }\end{array}$ \\
\hline 5 & Poor & $\begin{array}{l}\text { Corrosion affects ship's potential to } \\
\text { remain seaworthy, require immediate } \\
\text { repair/ maintenance actions. Thickness is } \\
\text { below allowable margin/ class minimum }\end{array}$ \\
\hline
\end{tabular}

\section{E. Characteristics of CH Monitoring System}

Incorporating following characteristics would 
significantly improve the effectiveness $\mathrm{CH}$ monitoring systems:

1) User Friendly: The system must be simple to install, use and interpret by the operators.

2) Knowledge Base: System must be developed based on latest knowledge base covering all vital information.

3) Accuracy: Erroneous interpretation may seriously affect the credibility and usefulness of the system.

4) Maintainability: The system must be amenable for periodic maintenance and addition of new knowledge base.

5) Cost effectiveness: The whole system must be cost effective for development, usage and maintenance.

\section{MERITS OF DEVEloping CH MONITORING SYSTEM}

The shipping industry needs a rational approach to perform corrosion inspections of ship structure. In order to reduce, if not eliminate, the effects of corrosion related failures, we must closely monitor the corrosion-prone areas. A combination of the preventive methods along with an efficient $\mathrm{CH}$ monitoring system for ship operations is essential to reduce the effects of corrosion. A well conceived and implemented monitoring system has the potential to ensure reliability, minimize risk and reduce major removal of hull structure, which in turn will extend the life of ship. The suggested $\mathrm{CH}$ rating method utilizes a system to assess the corrosion status of major compartments/ whole ship structure and points to critical and recurring corrosion problems in the ship. It also triggers the urgency/ quantum of repair actions and will be a useful indicator for the stake holders to take informed decisions.

\section{CONCLUSION}

A Corrosion Health assessment system to quantify the extent of corrosion on steel ship structures is presented. The inspection criteria and a six stage system in which whole structure is divided into corrosion zones for systematic corrosion assessment is explained. A rating scale of 10 to 5 is suggested and the effort of ship owner should be to maintain a minimum $\mathrm{CH}$ of 7 and above throughout ship's operational life to ensure the seaworthiness of ships.

\section{REFERENCES}

[1] T. Marchant, "The feasibility of a corrosion resistant ship," BMT Defence Services, White Paper, pp. 6-12, 2009.

[2] J. K. Paik, A. K. Thayamballi, Y. I. Park, and J. S. Hwang, "A time dependent corrosion wastage model for seawater ballast tank structures of ships," Corrosion Science, vol. 46, 2004.

[3] D. N. Veritas, "Corrosion protection of ships," Recommended Practices, Veritasveien, 1, N-1322, Hovik, Norway, pp. 6-20, 2000.

[4] J. Parente, J. C. Daidola, N. S. Basar, and R. C. Rodi, "Commercial ship design and fabrication for corrosion control," Report no. 5087.ION-I, New York, 1996, pp. 3-16.

[5] Hydrex, "How to choose the right ship hull coating system, from an economic and environmental perspective - an executive manual," White Paper, Ship Hull Coating Systems, 2011.
[6] American Bureau of Shipping, Guide for Hull Inspection and Maintenance Program, pp. 1-8, September 2012.

[7] P. R. Roberge, Corrosion Inspection and Monitoring, John Wily \& Sons, 2007, ch. 2, pp. 190-219.

[8] G. Wang et al., "Condition assessment of aged ships and offshore structures," in Proc. 17th International Ship and Offshore Structures Congress, Seoul, Korea, August 16-21, 2009, vol. 2.

[9] IACS PR 33, "Owner's hull inspection and maintenance schemes," July 2009.

[10] I. Perez, M. DiUlio, S. Maley, and N. Phan, "Structural health management in Navy," Structural Health Monitoring, pp 199-207, 2010.

[11] D. Geary, J. L. Dawson, and D. G. John, "An historical perspective of the management of aging infrastructures," presented at NACE Meeting, Dubai, April 1997.

[12] A. Mathiazhagan and P. K. S. Babu, "New horizon in ship's safety and reliability - corrosion management approach," presented at the 3rd Asian Symposium on Materials and Processing, Indian Institute of Technology, Chennai, India, 2012.

[13] D. N. Veritas, "Risk based corrosion management," DNV-RP-C302, Recommended Practice, pp. 9-17, April 2012.

[14] A. M. Berendsen, "Ship painting: Current practice and systems in Europe," in Proc. Protective Coating Europe, Sep. 1998, pp. 24-33.

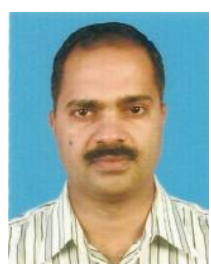

P. K. Satheesh Babu was born in Kerala, India on Jan. 11, 1971. The academic qualifications include B.Tech in naval architecture and ship building in 1993 from CUSAT, Kochi, India and M.Tech in corrosion engineering in 2001 from IIT, Mumbai, India.

He has 21 years experience in military and served in various naval ships, ship design, construction, quality control, and training institutions. Presently he is undergoing doctoral research in "Corrosion Assessment of Ship Structures” from CUSAT, Kerala, India. His major contributions are publication of papers "Effect of Temper on Environmental Assisted Failure in 7010 Aluminium Alloy", Paper 02435, Corrosion, 2002, "Effect of Form Parameters on performance of Ships", Conference on marine Hydrodynamics, NSTL, India, 2006, "New Horizon in Ship Safety and Reliability - Corrosion Management Approach", $3^{\text {rd }}$ Asian Symposium of Materials and processing”, IIT, Chennai, India, 2012.

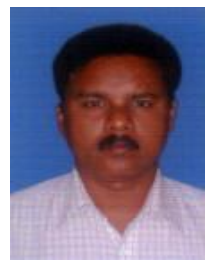

A. Mathiazhagan obtained BSc degree in chemistry from Bharati Dasan University, Trichy, India in 1990 and took master degree in applied science from Anna University, Chennai, India in 1992. He subsequently acquired master Degree in engineering with specialization of material Science from NIT Trichy, India, in 1994. He obtained his PhD in the year 2011 from CUSAT, India in the area of marine corrosion and protection. He is now serving as an associate professor at the Dept. of Ship Technology, CUSAT, India. He has several papers to his credit, of which 10 are in national and international journals and seven are in conferences/ seminars. He is a consultant in marine corrosion and protection. $\mathrm{He}$ is member of review committee in national/ international journals. He has attended more than 10 short courses in chosen areas and presented technical presentation in various training programmes.

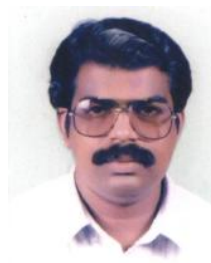

C. G. Nandakumar was born in 1961 and graduated in civil engineering from Govt. College of Engineering in 1983. He Obtained M. Tech and Ph. D in ocean engineering from IIT Madras in 1986 and 1990 respectively. He is presently working at CUSAT as a faculty member since 1992 . Produced $7 \mathrm{PhDs}$, guided 65 M.Tech dissertations and published 80 papers in various structural problems.
Journals and Conferences. His research interest is 